\title{
Balam Rodrigo: Selected Poems
}

\author{
Balam Rodrigo, Alicia Rueda-Acedo
}

From Hábito lunar (2005)

\section{Nomads of air}

Tonight I will dream you because the moon is in the window and it bathes me with its white light. There's a bright starry night that grows along with your smile. The silent wind blows through my hair, the wind and the silence.

\section{/silence}

A window, a highway, a streetlight, a man writing a poem under a new roof, under the same sky, sharing the same moon. Moon water. Mirror water. Nightly glow. You will see the same moon as me. The moon is the reflection of ourselves. Empty reflection. The heart is the reflection of the man, but a man cannot see another man's reflection unless he has a graceful heart. A bird, a crow. The night descends in its wings and my eyes fill up with dust. Dark dust. Dust in the air

$$
\text { / pollen }
$$

Bitter leaves are the hours abandoned in my body, the scars on my hands, the moon rain bathing the bodies that recoil and inflame with desire.

What desire? We are from the air. We are the nomads that walked naked through the desert on a stream of air. I remember we ate pomegranates, that is why your lips are crimson red. With amber eyes, ebony hair and 
infinite curves, you are the labyrinth of the world and I, the small Minotaur caged in your womb, gasping for air, picking flowers, chewing on nothingness and the grass in my hand,

/the grass in my hand.

From your infinite womb sprouts the grass, watered by the rain and bathed in moonlight. You turn to me and softly speak: My dear, tomorrow's seed has blossomed. It is time to sow our bodies with kisses, to plow them together, to bathe ourselves with smiles, to reunite in eternity and grab desire with our hands. It's time to break our lips apart, to kiss each other's flesh, to dim the light from the lamp, to eat fruit from the vine and sleep intertwined together under the dusk skies. Under the dusk skies. Under the tree.

/naked under the ceiba

The leaf of a tree bare, beaten, and dead; falls. Tonight I propose that the leaf from the ceiba tree is to be me, that I shall blend in with the dirt, that I shall fall like a shooting star. I propose that weeds shall grow in my throat and that on this same night the bats take my tongue, and that they may take this pollen faraway, ripe, and be handed to you. Raise your hand towards the sky, raise your hand

/raise your hand.

Now you can take my heart with your left hand, look around, see this vast land full of dreams. Take my eyes, look at this land of dreams, it's time to dream, it's the moment to dream. Come, hug me

/let's dream 


\section{From Bitácora del árbol nómada (2011) The Bare Souls}

1.

Envision life between your legs.

Envision my senses exploring your world:

I am terrestrial when I explore your body.

Creating thousand of suns underneath your womb.

Acrobats defying the fire, we fall in love

as

love.

2.

As we lay bare, vulnerable to the wind And anoint ourselves with the moon. Learn to keep time with each breath, the moans of the forgotten gods:

There, the souls of the bare lovers ignite.

3.

Love is a scar

that tear us apart

The effigy of your breasts call for me 
Love is the rump

that I ride to die

Love is a burning fire

is a tongue

digging us apart from air.

4.

Unaffected by relentless hate, implacable, we rise above, walking on water:

Loving is the downfall of the Gods

5.

Battle tanks, horses, suns, all returning wounded, the days worn out:

The journey of the bare souls exhausts them.

The bare souls dream through darkness, dreaming of solace through the rain: until the rain:

Their drowning hearts taste like cider.

6.

The House of the Bare Souls is clean of memories:

A loud heart comes running down the stairs. 
The flower, the dusk, the fallen fruit.

There is no other home for the bare souls than the silence and the air the other breathes.

7.

I kissed the air that lays

between your breasts

and it left me feeling your soul.

I am blind with nectar

but not with venom:

A man's desire lays where

the apple,

the croup,

and the clean breasts

of temptation

rest.

8.

Kill me with your poison and deadly nudity, and free me from myself.

9.

My love, I want the fruits of your dreams. 


\section{From Braille para sordos (2013)}

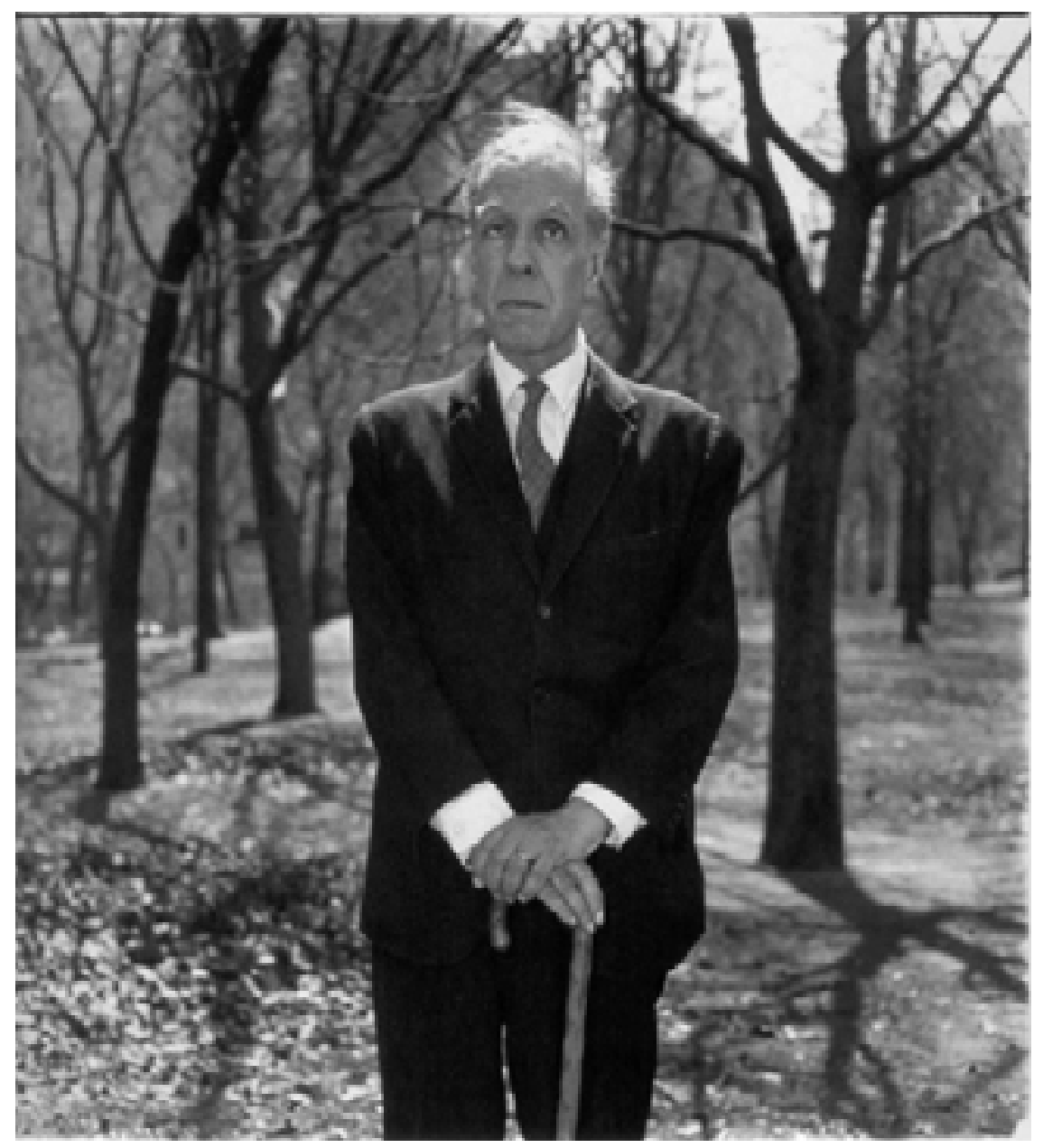

Jorge Luis Borges, Central Park, New York (Diane Arbus, 1969)

13.

a) Only the blind ones dream of the sun. They dream in negative, as the sun from their reveries eternally bleeds a pitch black light. In the kingdom of the Big Apple, where the masses wander with blind hearts, Diane Arbus - the seer with the mechanical eye - is queen. She too dreams of the sun, the grand, open, dripping sex drowned upon the heavens. Borges dreamt of the same sun, a headless sun that spilled the harsh light form its neck, in endless streams of syllables: glimpses of an Aleph with no name.

b) The iris is pierced by silver arrows of photography: Diane and her quiver of light. 
c) Tendrils of snow caress the heart and set it ablaze while dark roosters or dark poplars behead the moon with the branches or crests, waves of the sea in flames, shades of golden red, jugular blood staff on which Borges leans before the camera.

d) Plant sees of truth in your eyes, and they will draw crows from your heart.

\section{From Desmemoria del rey sonámbulo (2015)}

\section{Wounds of salt}

This is the sea, the blood, the grass.

This is the heart not able to scream, this is the land.

This is the eye that is able to see as a minimal consciousness, shards of water and matter.

This is the water in the palm of God's hand.

This is His language, His imperfect and funereal sign.

This is the sea and its turning tides eroding memories, tombstones of salt, wounds of death on the grass of blood:

Here are the high and walled pages of sand. 


\section{A Bird's Cry}

I'm a bird drowning in my own melody, exiled into the shadows.

Spellbound by the tree branches

fruit bearing sun

I'm so sick of the air.
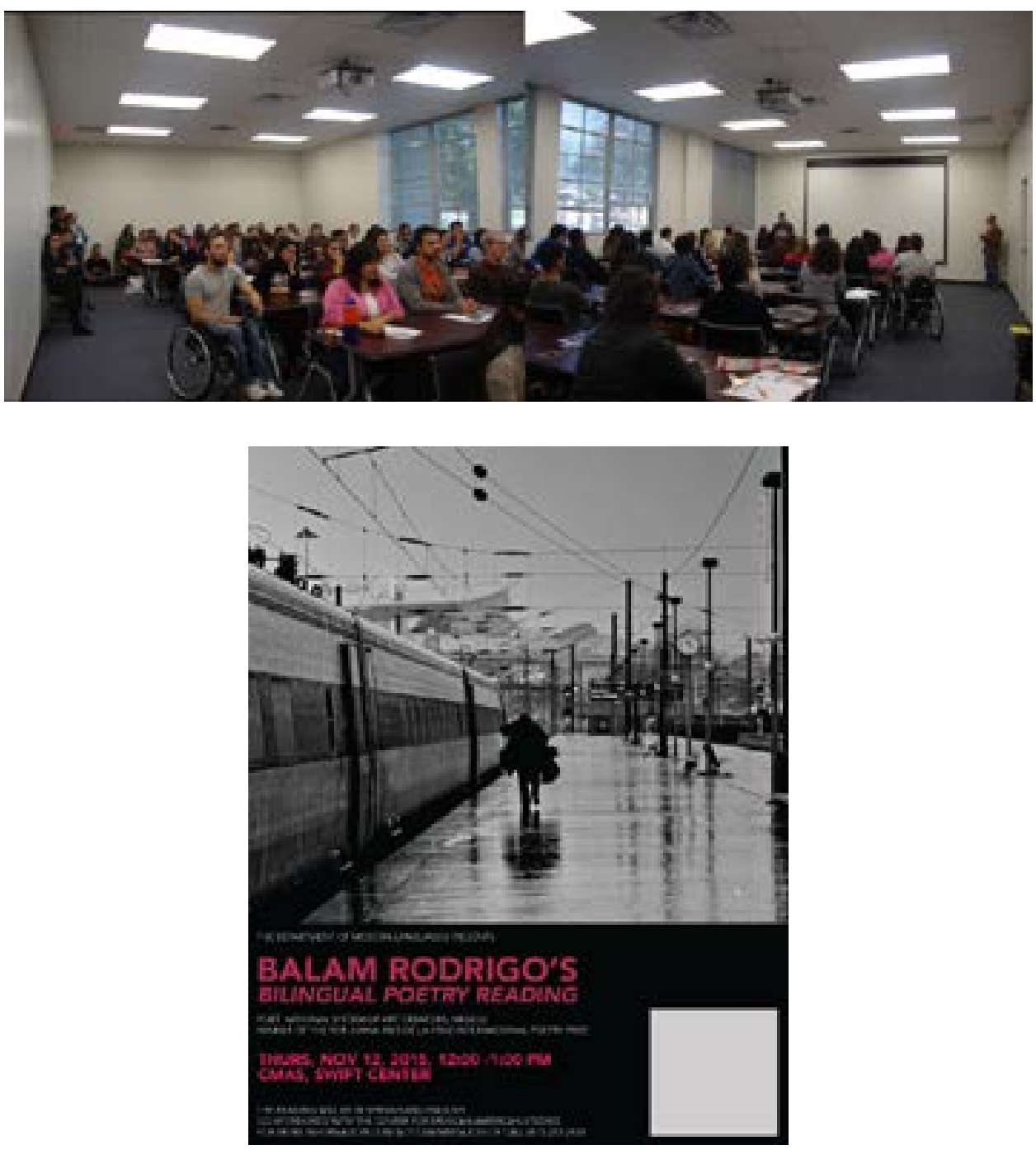


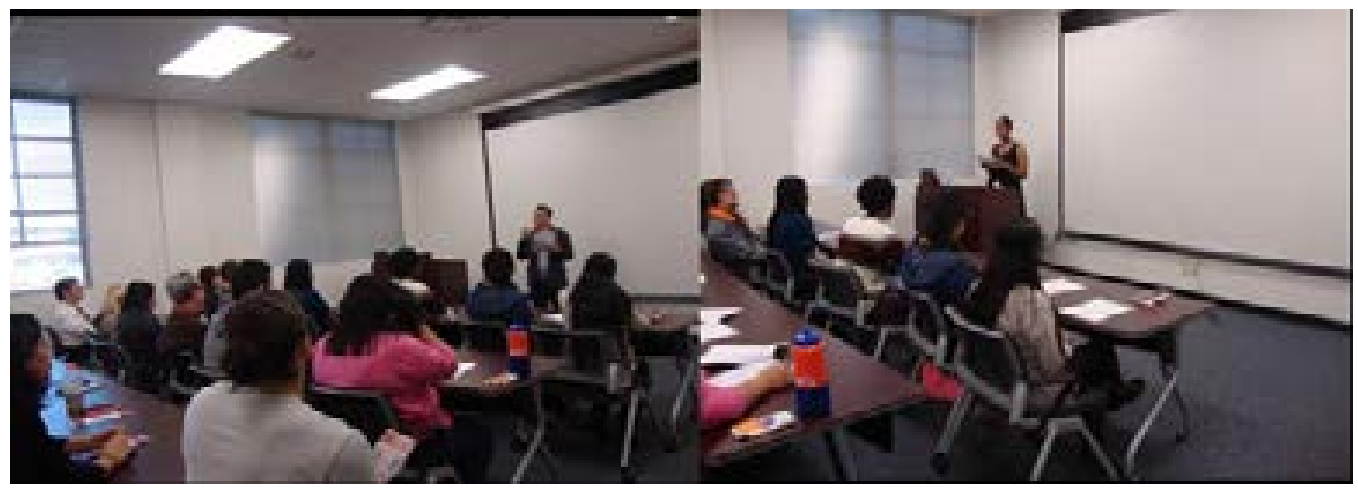

Balam Rodrigo reciting one of his poems \& a student reciting one of Balam Rodrigo's translated poems 